\section{Present Status of the Modified Widman Flap Procedure*}

by

SiguRd P. RAMFJORD, L.D.S., PH.D. $\dagger$

According to Webster's dictionary: " "flap is a piece of tissue partly severed from its place of origin for use in surgical grafting and repair of body defects". Traditionally flap procedures have been used for three purposes in periodontics: (1) surgical elimination of periodontal pockets; (2) to induce reattachment and bone regeneration in periodontal pockets; (3) to correct gingival and mucogingival defects and deficiencies. A flap procedure originally developed for one of these objectives may later have been used to serve a second or third purpose.

\section{HistoricAl BACKGROUND}

It has always been difficult to establish priorities of procedures used in dentistry, because oral communications often have preceded written descriptions and the descriptions have not always been written by the person who gave the oral communication. Language barriers may also have contributed to the numerous misinterpretations and disregard of historical data in the periodontal literature.

Neumann ${ }^{2}$ in 1912 and 1915 described a semilunar incision in the gingiva for access to the root surfaces and the alveolar crest. The description is vague and certainly does not delineate a flap operation for surgical pocket elimination. However, in the third edition of Neumann's textbook in 1920, a mucoperiosteal periodontal flap procedure is well described. ${ }^{2}$ Following elevation of a crevicular mucoperiosteal flap, the inflamed tissues on the inside of the flap are removed with sharp spoons as are tissues adherrent to the teeth and the alveolar process. He stresses that the surgery should result in horizontal alveolar gingival atrophy. Bony spurs and ledges are removed with a chisel until the alveolar process has the appearance of horizontal bony atrophy. Then he trims the flap so it fits snugly over the bone and to the surface of the teeth interproximally as well as bucally and lingually. He even recommends recontouring of the gingiva with a cauter if the contour following the healing of the flap surgery is not as desired.

Widman $^{3}$ in 1916 appears to have been the first to describe flap surgery for pocket elimination. Although,

* This work was in part supported by Grant \#DE 02731 U.S.P.H.S.

$\dagger$ The University of Michigan School of Dentistry, Department of Periodontics, Ann Arbor, Mich 48109.
Cieszynski ${ }^{4}$ in 1914 in a discussion referred to periodontal flap surgery for access for scaling and removal of granulation tissue and reduction of pocket depth. However, no description of the methodology was given.

The English edition of Widman's article in $1918^{3}$ gives a detailed description of a mucoperiosteal flap design which separates the collar of epithelium and inflamed connective tissue around the neck of the teeth from the flap. Subsequently, this soft tissue collar is removed and the bone is trimmed to reconstruct "the same anatomical form as in ordinary alveolar atrophy". The buccal and lingual flaps do not fit together interproximally and the bone is left bare to granulate over in a way similar to common practice in current pocket elimination flap surgery. ${ }^{23}$

Widman in a modification of his original technique ${ }^{33}$ is the first person to describe the reverse bevel incision, although it had been alluded to previously by Cieszynski. $^{4}$

Zentler ${ }^{5}$ in 1918 also described the use of a crevicular mucoperiosteal flap in a manner similar to what Neumann described in 1920. All of these early flap procedures were developed for the purpose of surgical pocket elimination.

Apparently the first description of a flap procedure for the purpose of reattachment was given by Kirkland ${ }^{6}$ in 1931. He used the basic gingival mucoperiosteal flap design of Neumann (1920) for the initial flap, but instead of trimming the flap for surgical pocket elimination, he attempted to eliminate the crevicular epithelial lining and the inflamed connective tissues by curettage of the flap. His method has been used since by several investigators $^{7,8}$ as "open subgingival curettage" or "flap curettage" and judging on the basis of clinical probing, this method has provided a significant reduction in pocket depth both from gingival recession and reattachment (average $3 \mathrm{~mm}$ in one study). ${ }^{8}$

More often used for reattachment therapy however is the reverse bevel gingival mucoperiosteal flap ${ }^{9-12,24}$ of the Widman design, but without Widman's original attempt at surgical pocket elimination and without his recommended postsurgical exposure of the interdental bone. The method ${ }^{12}$ that we have described as modified Widman flap surgery first was brought to my attention in lectures by a Swedish dentist by the name of Birger Oestman during the 1930's. However, I have not been able to find any publication by Dr. Oestman describing his flap design which was called a Widman-Oestman flap. During the 1930's and 1940's gingivectomy was the most popular form of periodontal surgery and Oestman's modification of the Widman flap was used only for very advanced cases of periodontal disease especially in the maxillary anterior region in order to achieve acceptable esthetic results. This procedure as used off and on for many years was published in Spanish in $1959 .{ }^{9}$ A similar flap procedure later was described by Morris ${ }^{10}$ under the designation of "the unre- 
positioned mucoperiosteal flap", and by Harvey ${ }^{11}$ as "surgical reconstruction."

The term "modified Widman flap" was adopted to designate a flap procedure which has been modified by several persons and came to designate an open subgingival curettage for reattachment, although the original purpose of the Widman flap was surgical pocket elimination. Widman's name was retained in the designation since modifications by Oestman and others were based on Widman's original reverse bevel design, and Widman apparently deserves the credit for introducing a reverse bevel mucoperiosteal flap in periodontal surgery. It should be understood however, that the modified Widman flap is not identical to the original Widman flap. Neither is it identical to any other similar flap procedure. ${ }^{9-11}$

\section{Surgical Techniques}

The technique for the modified Widman flap surgery has been described in detail in $1974,{ }^{12}$ so only a brief summary will be given here.

The flap surgery should not be initiated until 1 or 2 months after completion of the hygienic phase of the periodontal therapy. The initial gingival incision should be made with a knife that can be directed parallel to the long axis of the tooth. If the buccal or lingual pockets are deeper than $2 \mathrm{~mm}$ this initial incision should be placed at least $1 / 2 \mathrm{~mm}$ away from the free gingival margin in order to assure complete removal of all crevicular epithelium, which otherwise would prevent connective tissue reattachment to the tooth following the surgery. If the buccal crevice is $2 \mathrm{~mm}$ or less and/or esthetic considerations are of great importance, one may use an intracrevicular or crestal incision starting at the free gingival margin to minimize postsurgical gingival shrinkage. The initial incision is continued toward the interproximal areas with a scalloping outline for the flap, which means that as the interproximal spaces are approached, the incision should be brought close to the tooth at the gingival margin, since the contour of the tooth determines that an incision parallel with the long axis of the tooth will reach the alveolar process 2 to 3 $\mathrm{mm}$ away from the tooth surface and thus separate the pocket epithelium from the flap. It is important for postoperative flap adaptation that only the very minimum of interproximal tissues are removed for elimination of the epithelial lining of the pockets. When the roots of the teeth are situated closely together, it is advisable to make the initial incision in such a manner that the interproximal papillae under the contact points will be separated from the flap and later removed. In order to assure flap coverage of the interproximal bone following the surgery, it is often advisable to exaggerate the scalloping effect of the initial incision by staying 1 to $2 \mathrm{~mm}$ away from the midpalatal surface of the teeth, while the interproximal incisions come close to the tooth surfaces. Vertical gingival releasing incisions are usually not needed. A full thickness flap is elevated for only 1 to $2 \mathrm{~mm}$ from the alveolar crest as needed for access to the root surfaces and the interproximal bone. A second incision is made around the neck of each tooth from the bottom of the pocket to the alveolar crest. This incision should not scratch the surfaces of the teeth. The third and final incision is made with a spear shaped narrow interproximal knife, as for instance, an Orban knife which has been sharpened many times. The buccal and/or lingual flaps are deflected by the flat surface of the knife or held aside by the assistant so the knife will be placed on top of the alveolar crest to dissect free the collar of gingival tissues, which has been separated from the buccal and lingual gingival flaps and the teeth. This last incision should follow as much as possible the surface of the alveolar crest and the interproximal bony septa. Care should be taken not to nick the root surfaces with the knife. The separated collar of gingival tissue is then removed with curettes. The parts of the root surfaces that are not covered by attached periodontal fiber endings should be carefully planed with curettes. Indiscriminate curettage of residual fiber attachment should be avoided since such action may interfere with connective tissue healing. ${ }^{13,14}$ All soft tissues are removed from the bony surfaces of intrabony lesions as recommended in 1931 by Kirkland. ${ }^{6}$ The removal of suprabony soft tissues should be accomplished with sharp dissection rather than curetting the bony surfaces to the extent that bone is removed. Avoid prolonged deflection of the flaps and drying of the bone. Use a sterile saline solution for irrigation, and suction rather than sponges when vision is needed. The flaps should be adapted to the bone and meet interproximally. Hold the flaps firmly in position with finger pressure and sterile gauze moistened in saline. If the adaptation of the flaps to the teeth and to each other interproximally is incomplete, the flaps may be trimmed or some bone removed from the outer aspects of the alveolar process in order to enhance the all important flap adaptation. The flaps are sutured together with individual interproximal sutures and 3\% Achromycin ointment is placed over the sutures and along the flap contacts with the teeth, then a surgical dressing is placed. After a week this dressing is removed, the sutures are removed, the teeth are polished and the patient is instructed in oral hygiene. It is advisable to have the patient come in for professional polishing of the teeth once a week for the first month following flap surgery in addition to maintaining good oral hygiene at home. A recall schedule for prophylaxis once every 3 months is recommended for the future.

\section{Advantages and Disadvantages of the MODIFIED WIDMAN FLAP}

The main advantage of the modified Widman flap procedure compared to curettage is the possibility of establishing an intimate postoperative adaptation of healthy collagenous connective tissue and normal epithelium to contacting tooth surfaces. It has been shown 
in both animals ${ }^{15}$ and humans ${ }^{16}$ that with close adaptation of the gingival tissues to the tooth surface, a marginal new epithelial attachment forms which tends to seal off the deeper area of the separation between the tooth and the surrounding connective tissues. Thus, the healing connective tissues may adapt as close to the clean tooth surface as to an implant. ${ }^{17}$ Reattachment with formation of cementum ${ }^{18}$ may develop gradually from the apical aspect of the lesion. Minimal or no inflammation is present in the area of connective tissue adaptation in such cases indicating that the active pathologic aspect of the pocket has been eliminated as a source of irritation. Apparently, the new marginal epithelial attachment acts as a protective umbrella against bacterial penetration along the surface of the tooth. Such areas may gradually develop a long thin epithelial attachment, ${ }^{14,34,36}$ which conceivably with persistant irritation may open up again as a pathologic pocket.

It is well established that reattachment can occur following lateral sliding flaps. ${ }^{19}$ Since the interproximal tissues are biologically identical to the labial tissues, it appears that with equally good flap adaptation interproximally as is obtained bucally in laterally sliding flaps, reattachment and readaptation should be obtained equally well interproximally as buccally.

An electron microscopic study by Listgarten ${ }^{20}$ has elucidated the ultrastructural features of healing between a surgical flap and the denuded tooth surface in monkeys. Similar findings in humans also have been reported by Frank et al. ${ }^{18}$. Regeneration of the junctional epithelium occurred against dentin and cementum. The ultrastructure of the reformed epithelial attachment was in every way similar to undisturbed junctional epithelium with hemidesmosomes, basement lamina and several layers of elongated epithelial cells parallel to the tooth surface. Connective tissue attachment and cemental regeneration over both exposed cementum and dentin was described..$^{21}$ The junction between the exposed tooth surface and the newly formed cementum consisted of a densely stained granular layer free of collagen fibrils which had a tendency to split during the preparation of sections. During early stages of healing, the collagen fibers within the new cementum had no specific orientation, but at a later stage bundles of fibrils appeared to be connected to gingival fibers. Several groups of two or three collagen fibrils were covered by apatite crystals indicating calcification. Other areas of collagen fibers extended into calcified newly formed cementum indicating that calcification had occurred at the surface of the cementum and had established connective tissue reattachment to the tooth following treatment. Electron microscopic observations of the dental gingival junction following a lateral sliding flap operation covering a previously denuded labial surface of a tooth has confirmed that healing similar to the experimental flaps also may occur to a pathologically exposed tooth surface. ${ }^{22}$

With the conventional types of reverse bevel flaps with or without apical repositioning, ${ }^{23}$ interproximal bone and sometimes the root surfaces are left denuded at the termination of the surgery. Eventually such an area will granulate over and healing occurs at a more apical level than following the modified Widman flap procedure..$^{24}$ In order to achieve pocket elimination and minimal return of pocket depth, the conventional type of reverse bevel flap surgery utilizes much more bone removal than the modified Widman procedure. Although some reduction of pocket depth by shrinkage also follows the modified Widman flap surgery, the chief aim of this operation is maximum healing and reattachment of periodontal pockets with minimum loss of periodontal tissues during and after the surgery.

Bone may heal into an intrabony lesion following a variety of periodontal procedures ${ }^{25}$ and such results are most desirable. However, it also has been found that in many instances when lost bone has not been regenerated to any appreciable extent, judged from repeated roentgenograms over several years, there may appear a consolidation of the bone crests and no indication of further bone loss, although, a thin probe may be inserted several millimeters along the tooth surface without bleeding, exudate and/or pain at the location of the previous pocket. ${ }^{26}$ While in other areas with obvious inflamed periodontal pockets there is a continuous loss of bone with time. It thus appears that the modified Widman flap surgery may be successful in maintenance of periodontal support and health by the mechanism of a long epithelial attachment and close connective tissue adaptation with or without reattachment of connective tissue, and with or without regeneration of bone. This concept of epithelial reattachment and close adaptation to the tooth, and, connective tissue adaptation with or without reattachment as a substitute for surgical pocket elimination in the maintenance of periodontal health and support, has been questioned by many clinicians who have been trained to equate success of periodontal therapy with pocket elimination..$^{27}$ Periodontal surgery traditionally has been considered a failure when a probe could be inserted more than $3 \mathrm{~mm}$ during followup examinations.

It has been established that prior to periodontal treatment a thin periodontal probe used to measure pocket depth will penetrate to the connective tissue attachment at the bottom of the pocket. ${ }^{39}{ }^{40}$ However, following periodontal therapy the probe may or may not $^{38}$ penetrate between the entire junctional epithelium and the tooth surface. It is also impossible to tell whether the probe actually is separating junctional epithelium from the tooth surface or just moving along crevicular epithelium closely adapted but not attached to the tooth.

Although of great academic interest, it is of little clinical significance whether the attachment level recorded post treatment is connective tissue or epithelium as long as both the attachment level and the underlying bone can be maintained without further loss 
and even with some gain over many years. Admittedly, a long epithelial attachment or close epithelial adaptation may represent an anatomical defect which may be at least partially penetrated by probing, but as long as there is no sign of bleeding or secretion during routine probing, the defect should not be considered as an active pathological pocket. The obvious reason for lack of clinically visible inflammation in these defects is absence of stainable subgingival plaque on the root surfaces when the pocket wall is deflected from the tooth.

According to recent tissue culture studies ${ }^{41}$ close adaptation of cells to a root surface that has been exposed in a periodontal pocket requires some removal or treatment of the cementum in addition to complete plaque and calculus removal. It has been shown that if plaque is left on the root surface during root planing it will eventually reinfect the pocket although there may be an apparent initial healing. ${ }^{42}$

It is becoming more and more evident that success following any type of periodontal treatment is beyond everything else dependent on creation and maintenance of a tooth surface which is biologically acceptable to the adjacent soft tissues. This means elimination and prevention of subgingival plaque formation.

The modified Widman flap procedure provides access for proper instrumentation of the roof surfaces and immediate closure at the dentogingival junction between the teeth and well fitting flaps. It is important that this junction also is covered by an Achromycin ointment and a surgical dressing to prevent plaque invasion during the first week of healing and tissue adaptation to the tooth.

It appears that plaque control and frequent profes-
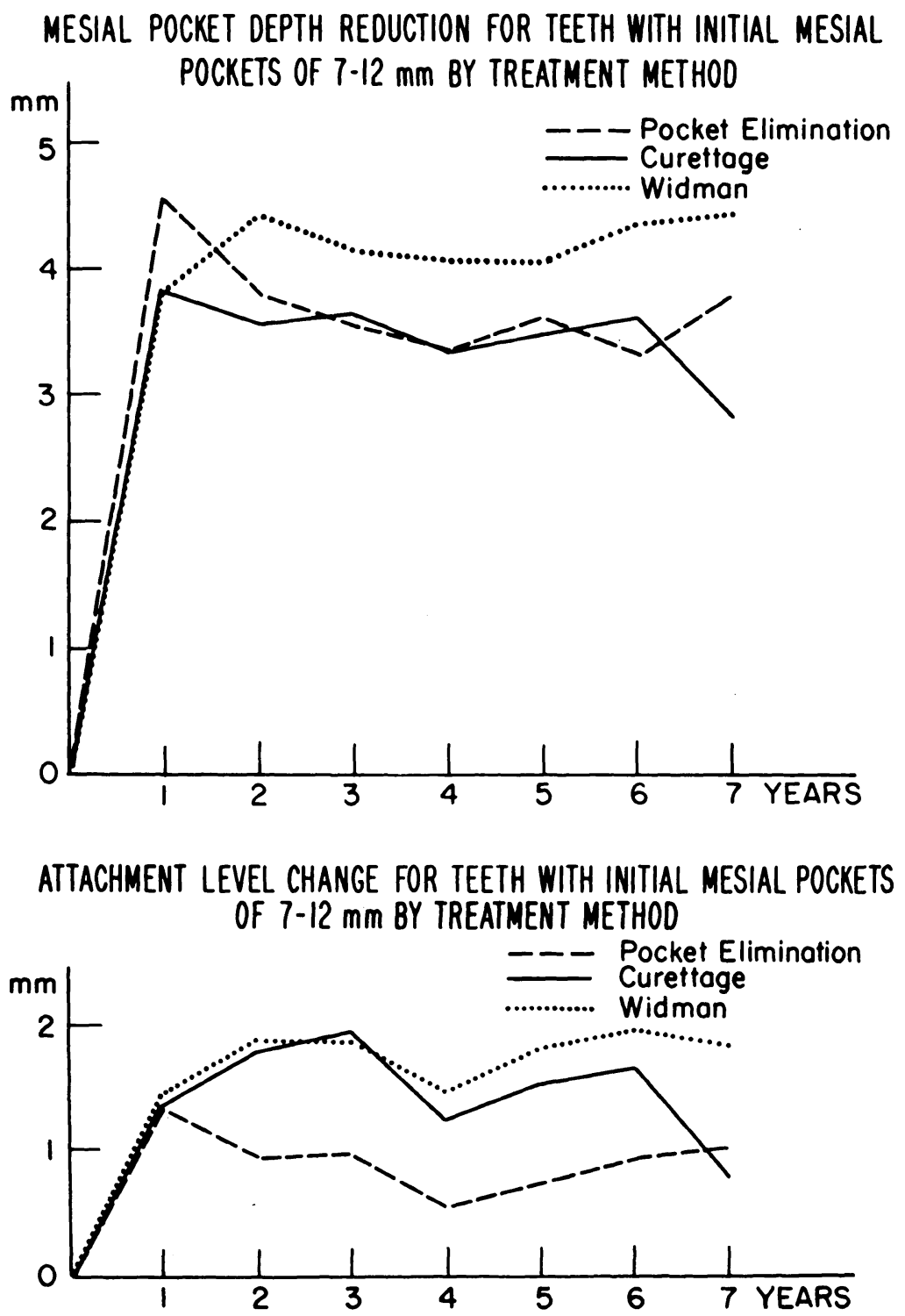

Figure 1. (top) Average pocket reduction for 7- to 12-mm pockets. Note that the initial reduction is sustained well for all methods of treatment, but best following the modified Widman flap surgery. Bottom figure shows an average gain of attachment over 7 years following all three methods, but better following the modified Widman procedure than following surgical pocket elimination. All graft illustrations in this paper are based on data from 105 patients studied longitudinally over 7 years. 
sional cleaning of the teeth is more important for the success of periodontal surgery than the type of operation. However, more attachment and new bone formation occurred following the modified Widman procedure than following other surgical methods on the basis of recall every 2 weeks for prophylaxis and strong emphasis on a plaque free mouth in a Swedish study ${ }^{35}$

However, in our longitudinal studies, often with less than optimal plaque control, ${ }^{37}$ and recall for profes-

\section{INTERPROXIMAL ATTACHMENT CHANGE FOR MANDIBULAR ANTERIORS BY TREATMENT METHOD-SEVERE DISEASE}

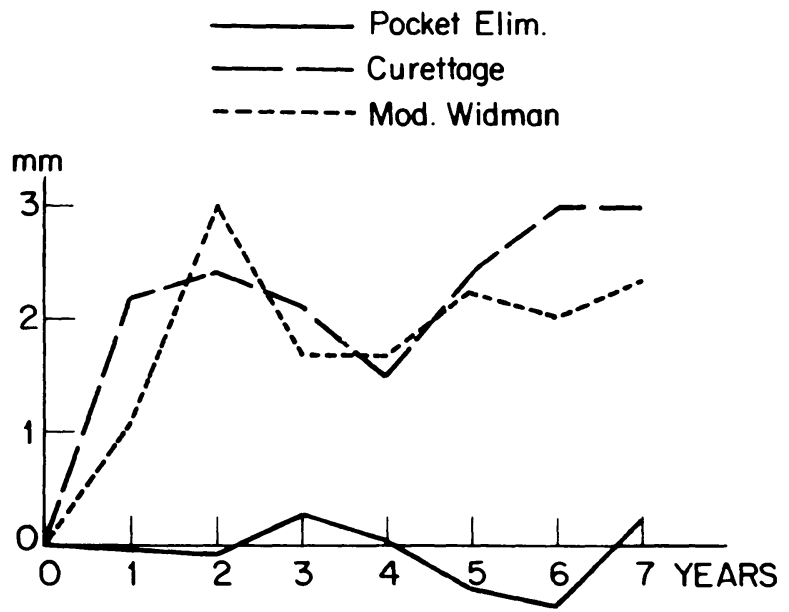

FIGURE 2. Average gain in interproximal attachment following treatment of 7-to 12-mm deep pockets. Note no gain following pocket elimination surgery. Mandibular anterior teeth.

\section{INTERPROXIMAL POCKET REDUCTION FOR MANDIBULAR ANTERIORS BY TREATMENT METHOD -SEVERE DISEASE}

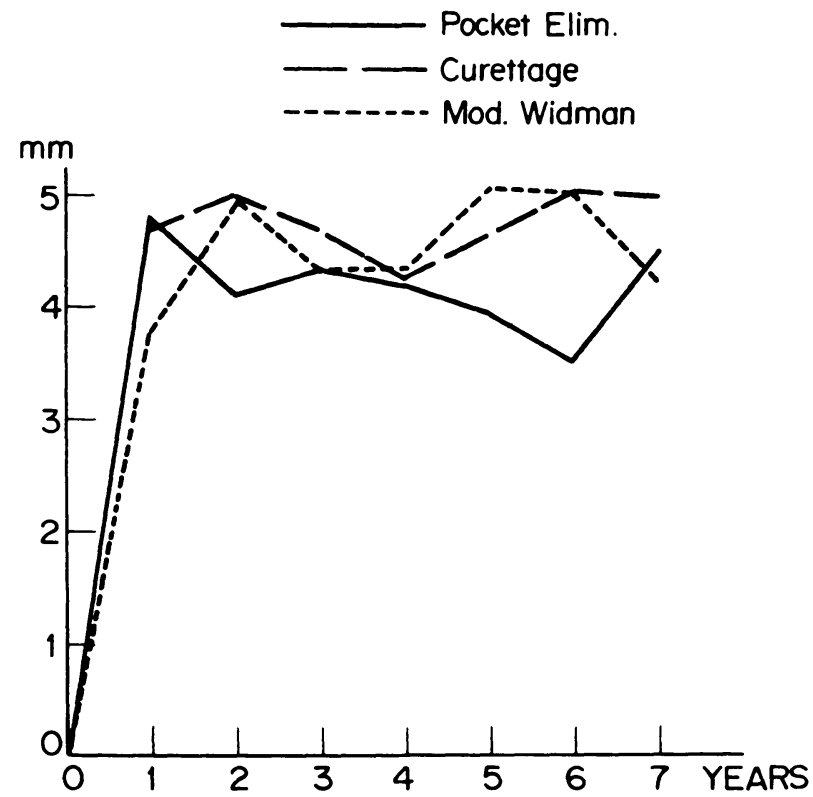

FIgURE 3. Average pocket reduction for 7-to 12-mm pockets (mandibular anterior teeth) is similar for all methods, and well maintained over 7 years.

\section{INTERPROXIMAL RECESSION FOR MANOIBULAR ANTERIORS BY TREATMENT METHOD-SEVERE DISEASE}

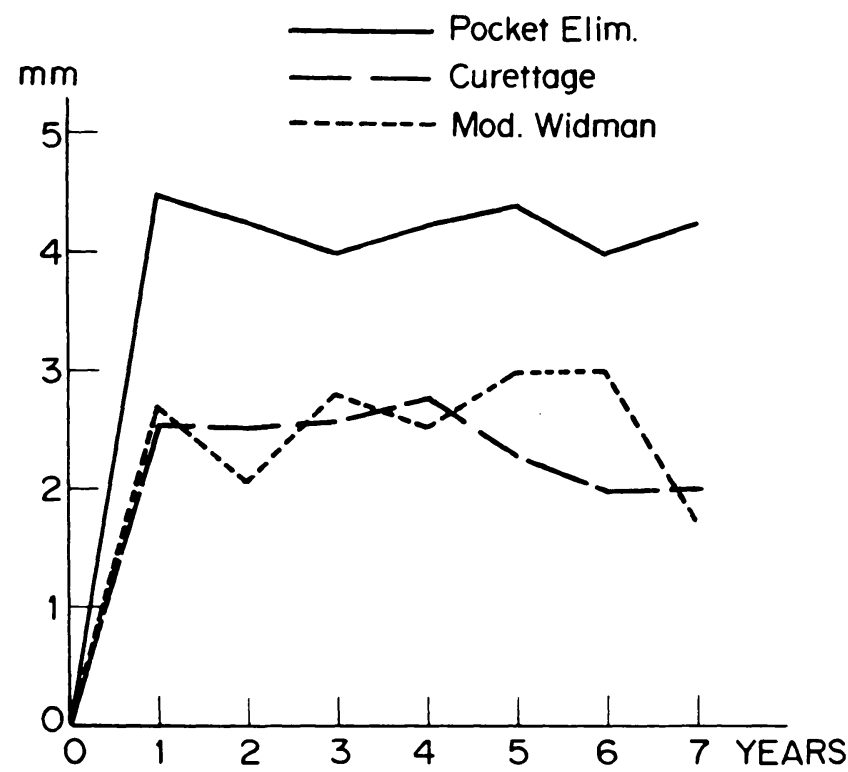

FIGURE 4. More recession is seen following pocket elimination surgery than following curettage and modified Widman flap surgery (mandibular anterior teeth with initial pockets of 7-to $12-\mathrm{mm}$.

sional prophylaxis every 3 months, excellent results have been maintained over 7 years of control. It also appears that recall once or twice a year for prophylaxis may be inadequate for successful maintenance care. ${ }^{29}$ The key to success of periodontal treatment is optimal healing within the pocket and prevention of new subgingival plaque extension. This may be achieved by good oral hygiene and frequent recalls for professional cleaning of the teeth without complete surgical pocket elimination. The obvious advantage of the modified Widman flap procedure compared with conventional reverse bevel flap surgery, including bone surgery, is conservation of bone and optimal coverage of the root surfaces by soft tissues following the modified Widman surgery. This means a more pleasing esthetic result, a favorable environment for oral hygiene and potentially less root sensitivity and root caries. It also tends to result in more pocket closure by reattachment ${ }^{30}$ and bone regeneration ${ }^{28,} 29$ than following the pocket elimination procedure over long term follow-ups (Fig. 1). For deep pockets in the mandibular anterior region, the results following subgingival curettage or modified Widman flap surgery are significantly better with regard to gain of attachment than pocket elimination surgery which hardly can be justified in that region (Figs. 2, 3, and 4).

The most important finding in our longitudinal studies is documentation rejecting the old concept that all periodontal pockets deeper than $3 \mathrm{~mm}$ had to be eliminated surgically in order to provide an acceptable prog- 
nosis for the teeth. The pocket as a pathological lesion may be treated successfully with various approaches and it is not even certain that any soft tissue and/or bone surgery is needed providing the root surfaces are treated properly ${ }^{30,32}$ and new plaque penetration is prevented.

One apparent disadvantage of the modified Widman flap surgery is the flat or concave interproximal architecture immediately following removal of the surgical dressing, especially in areas of interproximal bony craters. However, if meticulous oral hygiene is maintained, the interproximal tissues will regenerate over a few months with gain rather than loss of attachment, as measured clinically from the cementoenamel junction with a calibrated probe ${ }^{24}$ (see Fig. 1). In the long run, there is less interproximal recession following the mod-

\section{INTERPROXIMAL POCKET REDUCTION FOR MAXILLARY MOLARS BY TREATMENT METHOD - MODERATE DISEASE}

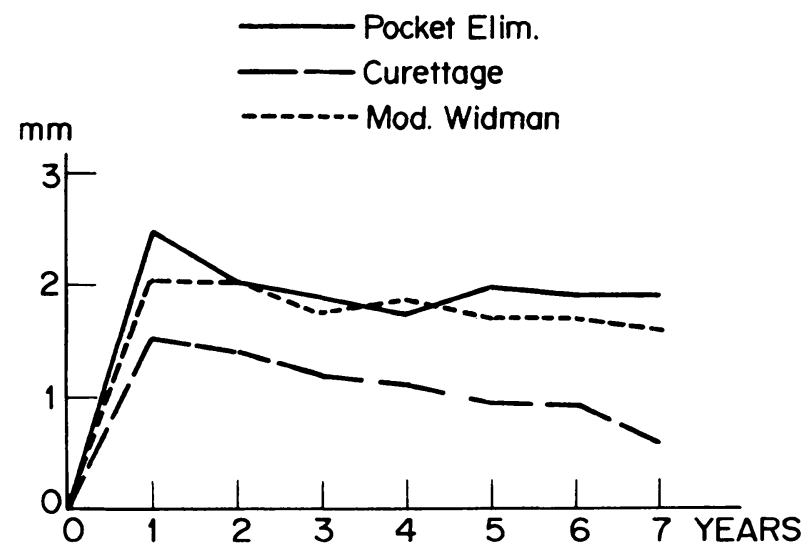

FIGURE 5. Interproximal pocket reduction (4- to 6-mm pockets) is greater and better maintained following modified Widman flap procedures than following curettage for maxillary molars.

\section{INTERPROXIMAL ATTACHMENT CHANGE FOR MAXILLARY MOLARS BY TREATMENT METHOD-MOOERATE DISEASE}

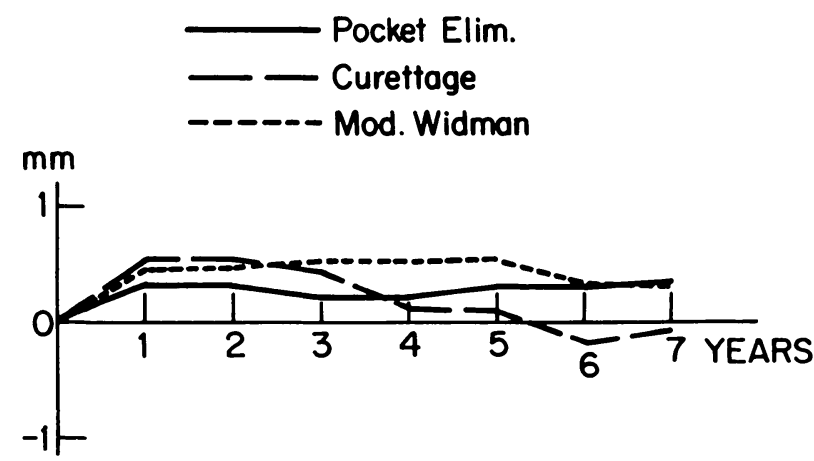

FIGURE 6. The interproximal attachment level is maintained better following the modified Widman flap than following curettage in maxillary molars (4- to 6-mm pockets).

\section{INTERPROXIMAL RECESSION FOR MAXILLARY MOLARS BY TREATMENT METHOD-MODERATE DISEASE}

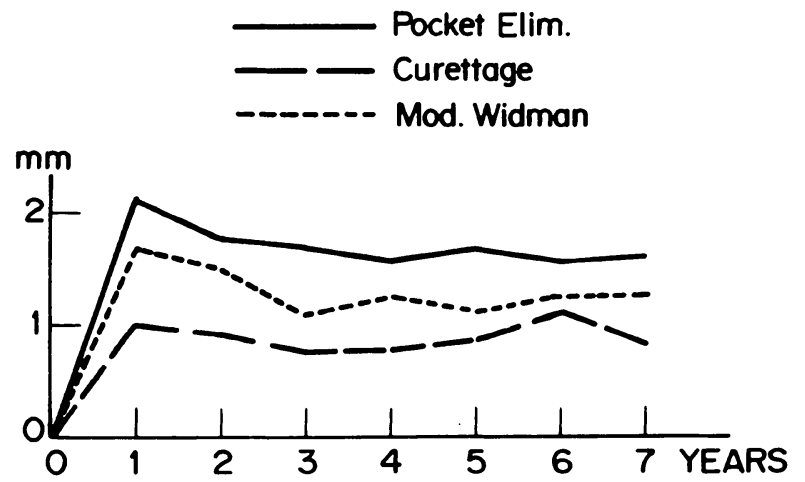

FIGURE 7. The interproximal recession is less following modified Widman than following pocket elimination surgery (maxillary molars, 4- to 6-mm pockets).

ified Widman procedure than following surgical pocket elimination.

The merits of the modified Widman flap procedure may be compared with subgingival curettage, since this type of flap operation actually presents a modification of subgingival curettage. The flap procedure provides better access to the root surfaces than curettage and allows for removal of the epithelial lining of the pocket with less trauma and better postoperative adaptation to the tooth than curettage. However, curettage has the advantage of not directly affecting the bone and the subpocket connective tissue attachment to the root. The short term results regarding maintenance of attachment is better following curettage than following the modified Widman procedure. ${ }^{24,31}$ The long term results are similar following curettage and Widman flap procedures in most areas of the mouth, but in the maxillary molar areas, the results of the modified Widman flap procedures seem to be better than following curettage (Figs. 5, 6, and 7). Selection of a procedure for individual cases should be based on convenience with regard to requirements of time and technical skill of the operator as well as esthetic and functional considerations. Minimal pain and discomfort for the patient also is an important consideration.

Surgical elimination of interproximal bony craters does not seem to be justified for maintenance of attachment level, ${ }^{24}$ since it does not offer any greater long term reduction in pocket depth than subgingival curettage or modified Widman flap surgery and leads to less gain in attachment (Figs. 8 and 9). On the basis of the findings of Rosling ${ }^{35}$ et al. osteoectomy for elimination of infrabony lesions also has a questionable rationale.

The modified Widman flap procedure is a basic technique when implantation of bone or other substances into intrabony lesions is contemplated.

Although statistical data are not available, it appears from our longitudinal studies that the response to periodontal therapy in partial furcation involvement is bet- 
POCKET DEPTH REDUCTION FOR TEETH WITH INITIAL POCKETS OF 4-6 mm BY TREATMENT METHOD

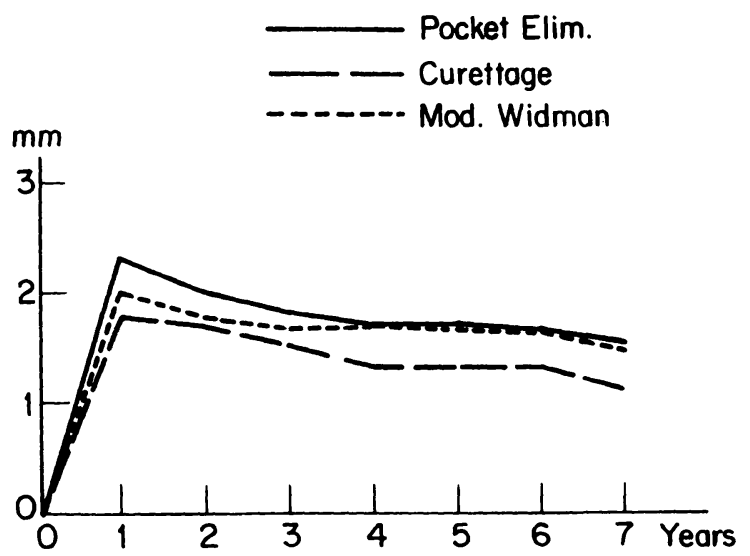

FIGURE 8. Average pocket reduction is the same over time following modified Widman and pocket elimination surgery (4- to 6-mm pockets).

\section{ATTACHMENT CHANGE FOR TEETH WITH INITIAL POCKETS OF 4-6 mm BY TREATMENT METHOD}

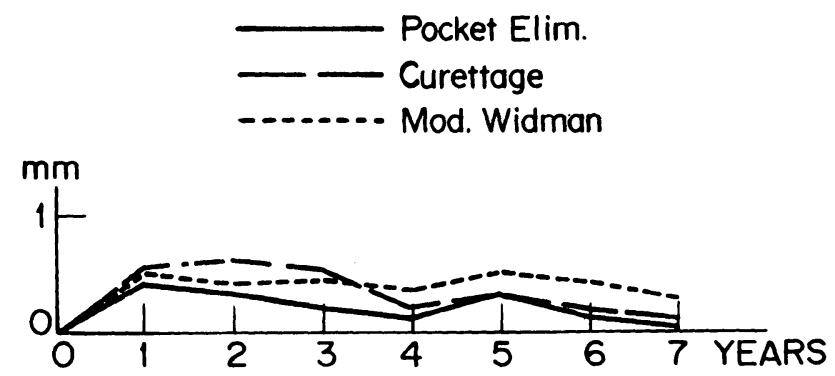

FIGURE 9. Attachment changes are most favorable over 7 years following modified Widman flap surgery, (4- to 6- $\mathrm{mm}$ pockets).

ter following modified Widman flap surgery than following either curettage or pocket elimination surgery. Modified Widman flap surgery provides better access to the furcation areas for root planing than curettage and the residual bone provides a better basis for healing than if the bony wall of the pocket was removed during the surgery.

\section{IndicAtions FOR the MOdified Widman FlaP Pro- CEDURE}

Although the modified Widman flap surgery may be applied successfully to the treatment of all types of periodontal pockets anywhere in the mouth, the greatest advantage of this procedure is in the treatment of (1) deep pockets, (2) intrabony pockets and (3) when minimal gingival recession is desired.

\section{REFERENCES}

1. Groove, P. B., and Staff (eds): Webster's Third New International Dictionary. Springfield, Mass., S. C. Merriam
Co., Publishers, 1961.

2. Neumann, R.: Die Alveolar-Pyorrhea und ihre Behandlung. ed 2, 1912, ed 3, 1920. Berlin, Hermann Meusser, ed 1,1912 .

3. Widman, L.: The operative treatment of pyorrhea alveolaris. A new surgical method. Sven Tandlak Tidskm (special issue) Dec. 1918.

4. Cieszynski, A.: Bemerkungen zur Radikal-Chirurgischen Behandlung der sogennante Pyorrhea Alveolaris. Deutsche Monatschr $f$ Zahnheilk 32: 575, 1914.

5. Zentler, A.: Suppurative gingivitis with alveolar involvement. J Am Med Assoc 71: 1530, 1918

6. Kirkland, O.: The suppurative periodontal pus pocket: Its treatment by the modified flap operation. $J$ Am Dent Assoc 18: 1462, 1931

7. Shaw, J. G.: Treatment of multiple periodontal pockets by extended flap operation. Paradontologie 16: 121, 1962.

8. Wade, A. B.: An assessment of the flap operation. Dent Pract 13: 11, 1962.

9. Ramfjord, S. P.: Reinsercion. Rev Assoc Odont Argent 47: $275,1959$.

10. Morris, M. L.: The unrepositioned mucoperiosteal flap. Periodontics 3: 147, 1965.

11. Harvey, P. M.: Management of advanced periodontitis. Part I. Preliminary report of a method of surgical reconstruction. $N$ Z Dent J 61: 180, 1965.

12. Ramfjord, S. P., and Nissle, R. R.: The modified Widman flap. J Periodontol 45: 601, 1974.

13. Levine, H. L.: Periodontal flap surgery with gingival fiber retention. J Periodontol 43: 91, 1972.

14. Levine, H. L., and Stahl, S. S.: Repair following periodontal flap surgery with the retention of gingival fibers. J Periodontol 43: 99, 1972.

15. Caffesse, R. G., Ramfjord, S. P., and Nasjleti, C. E.: Reverse bevel periodontal flaps in monkeys. $J$ Periodontol 39: 219,1968

16. Sullivan, H., Carman, D., and Dinner, D.: Histologic evaluation of the laterally positioned flap. IADR Abst No. $467,1971$.

17. Bodine, R. L., and Mohammed, C. J.: Histologic studies of the human mandible supporting an implant denture. Part II. J Prosthet Dent 26: 415, 1971.

18. Frank, R., et al.: Gingival reattachment after surgery in man: An electron microscopic study. J Periodontol 43: $597,1972$.

19. Sugarman, E. F.: A clinical and histological study of the attachment of grafted tissues to bone and teeth. $J$ Periodontol 40: 381, 1969.

20. Listgarten, M. A .: Electron microscopic study of the junction between surgically denuded root surfaces and regenerated periodontal tissues. I Peridont Res 7: 68, 1972.

21. Frank, R., et al.: Ultrastructural study of epithelial and connective gingival reattachment in man. J Periodontol 45: $626,1974$.

22. Listgarten, M.: Ultrastructural features of repair following periodontal surgery. S. S. Stahl (ed), Periodontal Surgery, Biologic Basis, and Techniques, Springfield, IIl. Charles C Thomas, Publishers, 1976.

23. Prichard, J. F.: Advanced Periodontal Disease, ed 2. Philadelphia, W. B. Saunders Co., 1972.

24. Ramfjord, S. P., Knowles, J. W., Nissle, R. R., Burgett, F. G., and Shick, R. A.: Results following three modalities of periodontal therapy. J Periodontol 46: 522, 1975.

25. Ellegaard, B., and Löe, H.: New attachment of periodontal tissues after treatment of intrabony lesions. $J$ Periodontol 42: 648, 1971.

26. Ramfjord, S. P., et al.: Longitudinal study of periodontal therapy. J Periodontol 44: 66, 1973.

27. Ramfjord, S. P.: Surgical Pocket Therapy. Int Dent J (in press) 1977. 
28. Kelly, G. P., Cain, A. J., Knowles, J. W., Nissle, R. R., Burgett, F. G., Shick, R. A., and Ramfjord, S. P.: Radiographs in clinical periodontal trials. J Periodontol 46: $381,1975$.

29. Rosling, B., Nyman, S., and Lindhe, J.: The effect of systemic plaque control on bone regeneration in infrabony pockets. J Clin Periodont 3: 38, 1976.

30. Zamet, J. S.: A comparative clinical study of three periodontal surgical techniques. J Clin Periodont 2: 87, 1975.

31. Burgett, F. G., Knowles, J. W., Nissle, R. R., Shick, R. A., and Ramfjord, S. P.: Short term results of three modalities of periodontal treatment. J Periodontol 48: 131 , 1977.

32. Morrison, E. C., Ramfjord, S. P., and Hill, R. W.: Short term effect of presurgical treatment on attachment level and pocket depth. IADR Abstract No. 516, 1977.

33. Widman, L.: Einige Erinnerungen hinsichtlich der Arbeit von Neumann: Die radikal-chirurgischen Behandlung der Alveolar-Pyorrhea. Vierteljahrshr $f$ Zahnheilk 39: 18, 1923.

34. Yukna, R. A.: A clinical and histologic study of healing following the excisional new attachment procedure in Rhesus monkeys. J Periodontol 47: 701, 1976.

35. Rosling, B., Nyman, S., Lindhe, J., and Jern, B.: The healing potential of the periodontal tissues following different techniques of periodontal surgery in plaque-free dentitions. A 2-year clinical study. J Clin Periodont 3: 233, 1976.

36. Yukna, R. A., Bowers, G. M., Lawrence, J. J., and Fedi, P. F.: A clinical study of healing in humans following the excisional new attachment procedure. $J$ Periodontol 47: $696,1976$.

37. Knowles, J. W.: Oral hygiene related to long-term effects of periodontal therapy. J Mich Dent Assoc 55: 147, 1973.

38. Caton, J., and Zander, H. A.: Osseous repair of an infrabony pocket without new attachment of connective tissue. J Clin Periodont 3: 54, 1976.

39. Sivertson, J. F., and Burgett, F. G.: Probing of pockets related to the attachment level. J Peridontol 47: 281, 1976.

40. Listgarten, M. A., Mao, R., and Robinson, P. J.: Periodontal probing and the relationship of the probe tip to periodontal tissues. J Periodontol 47: 511, 1976.

41. Aleo, J. J., DeRenzis, F. A., and Farber, P. A.: In vitro attachment of human gingival fibroblasts to root surfaces. J Periodontol 46: 639, 1975.

42. Waerhaug, J.: A method for evaluation of periodontal problems on extracted teeth. J Clin Periodont 2: 160, 1975.

\section{Announcement}

BOSTON UNIVERSITY SCHOOL OF GRADUATE DENTISTRY:N DIVISION OF CONTINUING EDUCATION

Boston University School of Graduate Dentistry announces the following courses:

Title: Periodontics for the General Practitioner

1. Understanding periodontal disease and its treatment .

DATES: September 7-8, 1977

2. Preparation of a case for treatment.

DATES: October 21-22, 1977

3. Definitive periodontal therapy.

Dates: December 8-10, 1977.

4. Management of the advanced periodontal disease case.

DATES: March 3-4, 1978.

5 . Therapy of the occlusal traumatic lesion

Dates: May 12-13, 1978.

6. Participation course in periodontal therapy.

Dates: June 9-10, 1978

Faculty: Henry M. Goldman, D.M.D., Dean Emeritus of the School, Professor of Stomatology

TITLE: Occlusal adjustment in the natural dentition.

Dates: October 13-14, 1977

Faculty: Hyman Smukler, D.M.D., H.D.D.

Gerald M. Kramer, D.M.D.

Thomas Mone, D.M.D.

TitLE: Restorative dentistry and periodontics for the advanced general practitioner.

Date: October 15,1977

Faculty: Howard M. SKurow, D.D.S

Myron Nevins, D.D.S.

TitLE: Clinical Solutions for the treatment of endodontic-perio-

\author{
dontic related problems. \\ DATE: October 27-28, 1977 \\ Faculty: Herbert Schilder, D.D.S. \\ Gerald A. Isenberg, D.D.S. \\ Title: Periodontal surgery. \\ DATE: November $10-11,1977$ \\ Faculty: Gerald A. Isenberg, D.D.S. \\ Alan M. Shuman, D.M.D. \\ Title: Periodontics for the dental hygienist. \\ Date: November 30, 1977 \\ Faculty: Nicholas Dello Russo, D.M.D., M.Sc.D. \\ GARY M. REISER, D.D.S. \\ TITLE: Clinical periodontal surgery \\ DATE: December 1-3, 1977 \\ Faculty: Gerald M. Kramer, D.M.D. \\ J. David Kohn, D.D.S. \\ TITLE: Management of clinical problems. "What to do when...." \\ DATE: December 3, 1977 \\ Faculty: Henry M. Goldman, D.M.D. \\ Herbert SChilder, D.D.S. \\ LEo TAlKov, D.M.D. \\ TitLe: Periodontal prosthesis \\ DATE: December 5-7, 1977 \\ Faculty: Gerald M. Kramer, D.M.D. \\ Myron Nevins, D.D.S. \\ Howard M. Skurow, D.D.S
}

For further information contact: Program Coordinator, Division of Continuing Education, Boston University School of Graduate Dentistry, 100 E. Newton St., Boston, Mass 02118. 